\title{
Friedrich Schlegel's early Romantic notion of religion in relation to two presuppositions of the Enlightenment
}

\begin{abstract}
$\mathrm{G}$ erman early Romanticism was an intellectual movement that originated in the era between the great French Revolution of 1789 and the beginning of the Napoleonic Wars in 1803. Usually, it is defined in contrast to the Enlightenment. The Enlightenment is presented as the age of reason, criticism and scientific naturalism, while the Romantics are portrayed as its reactionary enemies. According to a still customary prejudice, Romanticism was the age of exaggerated emotions, authoritarian dogmatism and mystical superstition. However, our notion of the Enlightenment has undergone changes in recent decades. Because the traditional antagonism between Aufklärung and Frühromantik has become questionable, the Romantic revival of religion needs reconsideration. In this paper, I propose an argument why the Romantics did not fall into reactionary irrationalism. My discussion focuses on one person, Friedrich Schlegel (1772-1829). I will present how two vital presuppositions of the Enlightenment, naturalism and criticism, were reinterpreted by Schlegel as pantheism and mysticism.
\end{abstract}

GERMAN EARLY ROMANTICISM (FRÜHROMANTIK) was an intellectual movement that originated in the era between the great French Revolution of 1789 and the beginning of the Napoleonic Wars in 1803. In this paper, I propose an argument why the Romantic revival of religion did not fall into reactionary irrationalism. My discussion focuses on one person, Friedrich Schlegel (1772-1829). In his time, Schlegel was the most famous literary theorist of German early Romanticism located in Jena and Berlin, but twentieth-century research has given him a reputation as a philosopher and historian as well.

Usually, Romanticism is defined in contrast to the Enlightenment. The latter is presented as the age of reason, criticism and scientific naturalism, while the
Romantics are portrayed as its reactionary enemies. According to a prevailing prejudice, Romanticism was an age of exaggerated emotions, authoritarian dogmatism and mystical superstition. However, our notion of the Enlightenment has changed over recent decades. Contemporary research acknowledges that the supporters of the Enlightenment were not abstract, calculating thinkers who only believed in the universal validity of (Occidental) reason. ${ }^{1}$ Thus, while our understanding of the Enlightenment has been revised, we need to reconsider the earliest phase of Romanticism in order to better understand the significance of both epochs. Because the traditional antagonism between the Enlightenment and early Romanticism has become questionable, the Romantic revival of religion needs further reconsideration.

I will focus on two essential presuppositions of the Enlightenment, which were naturalism and criticism (cf. Beiser 2000: 18). I discuss them in relation to Romantic religiosity. Religion was not a peripheral issue during the inauguration of modernity. As the German historian Reinhart Koselleck has claimed, both seventeenth century absolutism and the eighteenth century Enlightenment (which emerged mainly as a critique of the former), were framed by the Thirty Years' War (Koselleck 1988: 17). The Thirty Years' War (1618-48) was a religious conflict between Protestants and Catholics that actualised questions concerning the Christian origin of all political order.

1 The research results presented in this paper are partly based on my publication, Nivala 2011a. For a revisionist interpretation concerning the relationship between the Enlightenment and Romanticism, consult Stockinger 2003: 82-6; Beiser 2000: 45, 203; Beiser 2006: 43-55. See also Krauss 1980 and Schanze 1966. 
In Protestant countries, the legitimacy of the political system was based on the Apostle Paul's doctrine of submission to governing authorities (Obrigkeitslehre), contained in a letter to the Romans (Rom. 13:1). Martin Luther had emphasised this idea during the German Peasants' War (1524-6) in order to discourage rebelling peasants (Karthaus 2007: 17). There was clearly a tension between the Enlightenment's demands for a public critique of all authority, presented for example by Immanuel Kant, and this Protestant doctrine (see Kant 2004: A xii). Nevertheless, it was also equally possible to criticise the status quo based on Apostle Paul's political theology: there was a minor tradition of interpreting his letter to the Romans in a Messianic spirit, giving it revolutionary implications (Agamben 2005: 33). This repressed heritage discloses the possibility of understanding how the early German Romantics could appeal to arguments that prima vista seem religious, without compromising their political rebelliousness and critical spirit in relation to authority.

According to a commonly held prejudice, the Enlightenment was an age of emerging atheism, while Romanticism represented a religious revival. However, as Panagiotis Kondylis has claimed, the German Aufklärung was not as atheistic as the French and English Enlightenments were. In Germany, many famous Aufklärer were actually priests, while the Protestant ideal of individual religious freedom was understood to be compatible with the emancipatory programme of the Enlightenment. In Germany, the Enlightenment was not as opposed to Christianity as it was in Catholic France, where the church was connected with the ancien régime. Even the most radical Protestant movements, such as Pietism, shared some common premises with Aufklärung: for instance, freedom of religion and individual thought. (Kondylis 2002: 538-9.)

The Schlegel family is a good example: Friedrich Schlegel's father, Johann Adolf Schlegel, was a clergyman and literary theorist who contributed to public debates on the German Enlightenment. It is not difficult to find traces of J. A. Schlegel's influence in his son's early classical and political writings during the early 1790 os. Still, it is less obvious that the principles of the Enlightenment also played a major role during Friedrich Schlegel's later Romantic programme of new religion at the turn of the nineteenth century. It is true that Schlegel did not necessarily use the same terminology as the Aufklärer did, but I will suggest that there were still major confluences between the principles of thought from the late period of the En-

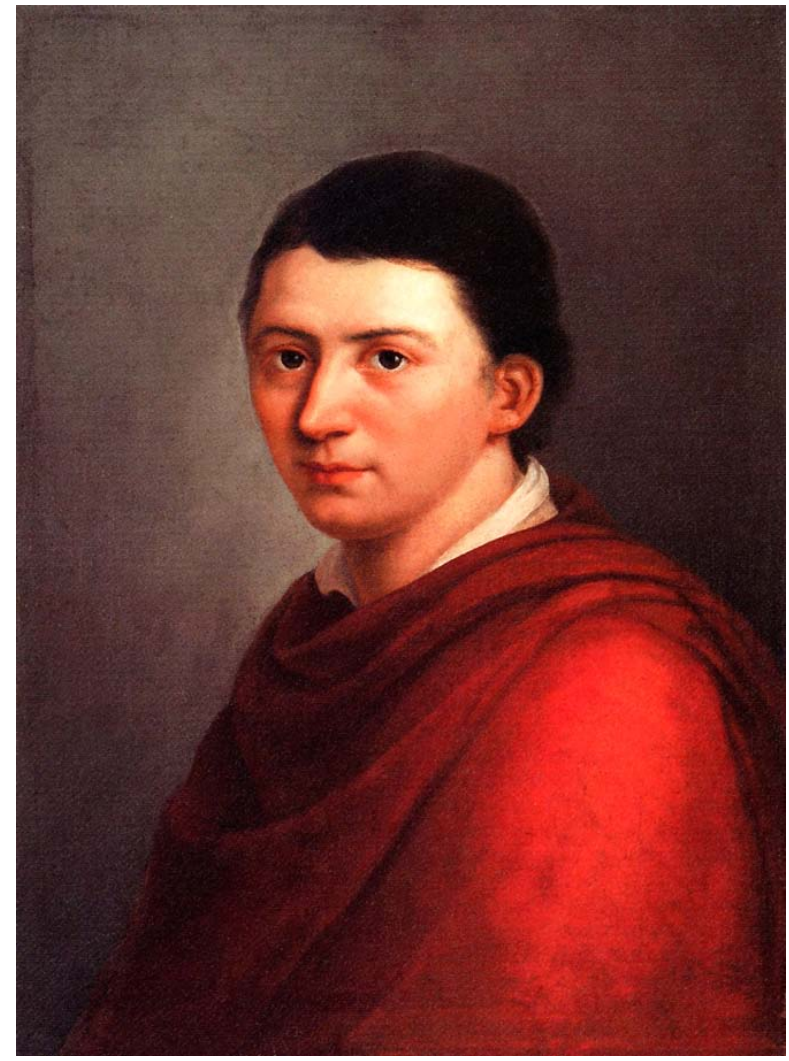

Friedrich Schlegel by Franz Gareis, 1801.

lightenment to early Romanticism. When it comes to religion, many themes that Schlegel emphasised were actually first suggested by Gotthold Ephraim Lessing (1729-81).

I will state my argument by making two theses that characterise the position of the German early Romantics in the history of ideas.

\section{Thesis I: Pantheism = Naturalism}

In an intellectual aftershock of an actual earthquake which took place in Lisbon at this time, there was a significant literary discussion which rocked the solid intellectual ground of Aufklärung, resulting in irreparable damage to its Leibnizian optimism. This havoc was wreaked by a pious man, Friedrich Heinrich Jacobi (1743-1819). The debate that Jacobi started between himself and Moses Mendelssohn was the so-called Pantheism Controversy. It dominated the German public arena in the 1780 os and gos. Jacobi launched his polemic attack on the Enlightenment by claiming in his book, Briefe über die Lehre Spinozas (Letters on the Doctrine of Spinoza, 1785) that the recently deceased Lessing, a great hero of the 
Aufklärung, had confessed to him that he had been a pantheist. ${ }^{2}$ Jacobi quotes from memory what Lessing had replied after he had read Johann Wolfgang von Goethe's poem Prometheus to him: 'Die orthodoxen Begriffe von der Gottheit sind nicht mehr für mich;

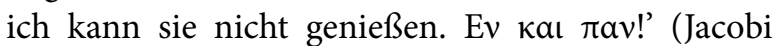
2000: 22). Lessing had resigned from the orthodox credo of Christianity with the exclamation hen kai pan: the slogan of pantheism. It means One and Allall-encompassing unity. ${ }^{3}$

Pantheism is a word that is subject to various misinterpretations, to be sure. In the eighteenth century context it implied that one was an atheist. During the 1780 os, the supporters of Baruch de Spinoza's $(1632-77)$ philosophy were still widely persecuted in Europe as atheists. In any case, Jacobi's intention was not to defame Lessing, but to claim that in fact all sympathisers of the Enlightenment were Spinozists, even though they did not necessarily understand this themselves. In his view, the Enlightenment's belief in the supremacy of the natural sciences was tantamount to fatalism and thereby necessarily led to atheism. According to him, the idea that nature is merely a great clockwork machine was typical of Spinozism. This kind of naturalism made it impossible to believe in free moral will and the immortality of the soul. 4 Jacobi's own solution to this crisis of the Enlightenment was salto mortale, that is, a leap of faith into the mystical abyss of Christianity. ${ }^{5}$ In the area of politics, one can say that the Lutheran Obrigkeitslehre corresponded to this blind leap of faith.

2 It is not really relevant to ask whether Jacobi is telling the truth about Lessing's convictions or not. More important are the cultural ramifications of his claim. Most contemporary scholars, at least, believed him, among them the young Friedrich Schlegel. See KFSA II: 107 .

3 On the Egyptian origins of hen kai pan and the connections of this phrase to Lessing's Freemasonry see Assmann 1998: 140.

4 Jacobi is usually portrayed as an irrational fideist, but this is actually misleading. Rather, Jacobi turned the critical apparatus of the Enlightenment against itself. In other words, he was already metacritical at the time at which Kant had just published his Kritik der reinen Vernunft (Critique of Pure Reason, 1781). Jacobi expressed a very real concern. The most difficult problem of the Enlightenment was how to combine normative criticism with scientific naturalism without reducing the freedom of will to the causal necessity of nature. Kondylis 2002: 19-22.

5 Jacobi 200o: 23-6. See also Timm 1974; Beiser 1987: 44-91; Henrich 2008: 91.
Thus, in the late eighteenth century German public arena, Jacobi’s Christian enthusiasm (Schwärmerei) and Lessing's pantheistic naturalism (Spinozismus) were presented as extreme opposites. One would assume that as a member of the Romantic movement, Friedrich Schlegel would have deprecated Lessing's pantheism and taken the side of Christianity in this debate. But this is not the case. On the contrary, Schlegel defended Lessing by writing an enthusiastic portrait of him, and by editing his collected works, Lessings Gedanken und Meinungen (Lessing's Thoughts and Opinions, 1804). (See KFSA III: 3-102.) Furthermore, Schlegel explicitly criticised Jacobi's fideism and his leap of faith. He wrote in a letter to his brother August Wilhelm about Jacobi's philosophical position:

... es ist sicher die alte Leyer vom Salto mortale. - Alle consequente $\langle\varphi \sigma\rangle$ [philosophische Systeme] führt zum Spinos.[ismus] Spinos[ismus] $=$ Atheismus - Atheismus ist - Atheismus; - also die Augen zu und Kopf

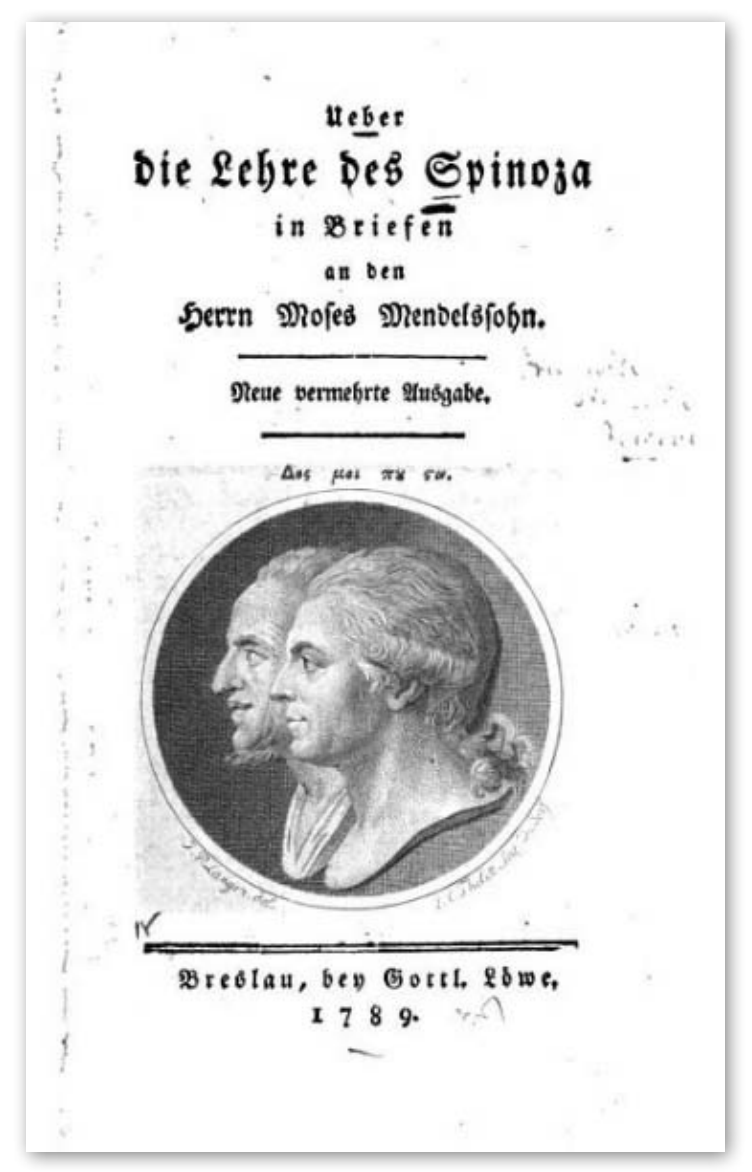

Briefe über die Lehre Spinozas: Letters on the Doctrine of Spinoza, 1785; 2nd, enlarged edition with important appendices, Breslau 1789. 
unter. . .Mein Anti-Jacobi ist eigentlich nur halbfertig. . . (Friedrich Schlegel to August Wilhelm Schlegel on 7 May 1799. KFSA XXIV: 283, No. 173.)

According to Schlegel, Jacobi's claim that Spinozism is atheism and it must be rejected simply because it is atheism, was a petitio principii. He wanted to raise objections to this sceptical trend in German philosophy. Thus, it would certainly be misleading to claim that Schlegel's position at the turn of the nineteenth century could be characterised as fideism. ${ }^{6}$

Although the members of the early Romantic movement objected to Jacobi's thought, they did read his book on Spinoza very carefully. But Schlegel obviously harnessed the book to ambitions contrary to its author's original intentions: it was used as an object lesson in the study of how to convert to this fashionable religion-how to become a pantheist. He writes in Gespräch über die Poesie (Dialogue on Poetry, 1800):

In der Tat, ich begreife kaum, wie man ein Dichter sein kann, ohne den Spinosa zu verehren, zu lieben und ganz seinige zu werden... Im Spinosa aber findet Ihr den Anfang und Ende aller Fantasie, den allgemeinen Grund und Boden, auf dem Euer Einzelnes ruht. . . (KFSA II: 317.)

According to Schlegel, it was impossible to be an original poet without taking Spinoza for an idol. Moreover, it is not particularly difficult to find explicitly pantheistic ideas in Schlegel's oeuvre. For example, he writes elsewhere in the same text:

Diese [die Poesie der Natur] aber ist die erste, ursprüngliche, ohne die es gewiß keine Poesie der Worte geben würde. Ja wir alle, die wir Menschen sind, haben immer und ewig keinen andern Gegenstand und keinen andern Stoff aller Tätigkeit und aller Freude, als das eine Ge-

6

It should be added that later on Schlegel converted to Catholicism. In his famous philological study on the common origins of Indo-European languages, Über die Sprache und Weisheit der Indier (On the Language and Wisdom of India, 1808), he condemns pantheism quite straightforwardly. KFSA VIII: 243-53. During the very same year, he converted to Catholicism. It is probable that he wrote those lines against pantheism to disclaim his own former beliefs. See also von Wiese 1927: 97-9. dicht der Gottheit, dessen Teil und Blüte auch wir sind - die Erde. (KFSA II: 285.)

Schlegel understood the whole of poetic literature only as a written expression of divine creativity. There was a universal poiesis (poetry, production, energon ${ }^{7}$ ) of the cosmos, on which written poetry depended. The Orphic idea of Nature's holy poetry has a long tradition in Western intellectual history (Hadot 2006: 92). For the Romantics, no such categorical opposition existed between scientific naturalism and religious pantheism as Jacobi claimed. On the contrary, it was exactly Spinoza's monism that was utilised to resolve the contradiction between religion and the natural sciences.

Although Spinozist tendencies were repressed in all orthodox Christian confessions, the German philosopher Dieter Henrich has reminded us that the tradition called the 'theology of the Spirit' was strong among the German Pietists. They based their Spinozist interpretation of the Bible on the Gospel of John and the Pauline epistles. There was a common origin for both St Paul's and Spinoza's monism that comes from two major sources: the Kabbalah and Stoicism (Henrich 2008: 104; Timm 1974: 160-3). According to the Apostle Paul, 'there are diversities of workings, and it is the same God who is working

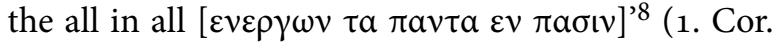
12:6). Similarly, the intellectual nucleus of Spinoza's Ethics holds that there is ultimately only one original substance-Deus sive Natura, God or Nature. (IV, Preface.) All other things in the world are only modifications (natura naturata) of this single creative substance (natura naturans). (I, Prop. 15.) It was possible to bridge the opposition between Christianity and Spinozism by interpreting the Bible in a certain way and to end up with an intellectually coherent position. ${ }^{9}$

7 See the next footnote.

8 As Giorgio Agamben has emphasised, energon ('working') is a technical philosophical term for Paul: 'Paul is clearly familiar with the typical Greek opposition dynamis/energeia, potency/act, which he uses more than once' (Agamben 2005: 96-7). The same Stoicism is also expressed in the Ephesians: 'the fulness of Him who is filling the all in all [ $\tau 0 \pi \lambda \eta \rho \omega \mu \alpha$

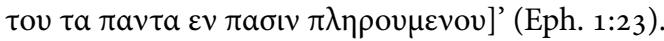

9 'Ever since the dawn of the Reformation in Germany, pantheism has been the religion of the radicals. The radical reformers. . .were attracted to pantheism because it supported their ecumenical, egalitarian, and liberal social ideals.' (Beiser 1992: 243.) 
But what ramifications did this thought have for Lessing's programme of the Enlightenment? In Spinoza's monism, there is a constant parallel between different epistemological levels and different ethical dispositions. The French philosopher Gilles Deleuze has interpreted Spinoza's system thus: 'The different kinds of knowledge are also different ways of living, different modes of existing' (Deleuze 1992: 289). The first level of knowledge is the imagination and the superstitious opinion which corresponds to the fear of authority as an ethical disposition. The second level is reason; intellectual knowledge that teaches us to distinguish true common notions from the false images belonging to the first kind of knowledge:

\section{...the second kind of knowledge also involves a second kind of religion: no longer a religion of imagination. . .this is no longer the religion of the prophets but, on its various levels, the religion of Solomon, the religion of the Apos- tles, and the true religion of Christ founded on common notions. (Deleuze 1992: 291.)}

But the progression of history does not stop with this kind of religion. The highest, third kind of knowledge in Spinoza's system is intuition. It corresponds to an active joy, love and beatitude as a moral and religious attitude (Deleuze 1992: 304-5). Actually, the third kind of knowledge means that we temporarily take God's viewpoint of the world: 'we come to form adequate ideas of ourselves and of other things as they are in God, and as conceived by God' (Deleuze 1992: 306).

Lessing's theology of the Spirit was structured around this interpretation of the Bible. He thought the structure of history was one which accorded with a divine economy of the trinity, based on Spinoza's triadic system. Thereby his description concerning the process of the universal Enlightenment of mankind had three stages as well. The age of the Father corresponded to the age of un-enlightened superstition and the childhood of humanity. The age of the Son was the current age of mature, modern subjects and rational, scientific study. Finally, the future age of the Holy Spirit would be the age of the everlasting gospel, ${ }^{10}$ during which people would perform moral actions spontaneously. (Lessing 1959: 25-6, \$85, 86.) What Paul announces about the end of history can be interpreted in a very similar way: 'and when all things may be subjected to Him, then the Son also himself shall be subject to Him, who did subject to Him all things, that God may be the all in all $[\theta \varepsilon o \varsigma[\tau \alpha]$ $\pi \alpha v \tau \alpha \varepsilon v \pi \alpha \sigma t v]^{\prime}$ (1. Cor. 15:28; see Agamben 2005: 55). Both the Father (Yahweh) and the Son (Jesus Christ) must withdraw in order that a united God could be the all in all, Theos ta panta en pasin. ${ }^{11}$

The Christian agape represents a self-sacrificing, reflective and active love. Divine love as a third kind of knowledge was the basis for the theology of the Spirit. Friedrich Schlegel shared this Lessingian ideal that the education of humanity must emerge from love: 'Nur durch die Liebe. . .wird der Mensch zum Mensch (KFSA II: 264, no. 83). Moreover, Spinoza was the greatest example of calm beatitude (Seeligkeit) for the Romantics. Schlegel describes Spinoza's third kind of knowledge which takes the form of original love:

Von der Art wie die Fantasie des Spinosa, so ist auch sein Gefühl. Nicht Reizbarkeit für dieses und jenes, nicht Leidenschaft die schwillt und wieder sinkt; aber ein klarer Duft schwebt unsichtbar sichtbar über dem Ganzen. . .welches in stiller Größ den Geist der ursprünglichen Liebe atmet. (KFSA II: 317.)

10 The expression 'the everlasting [or eternal] gospel' that both Lessing and Schlegel use is a reference to Joachim of Floris' interpretation of Rev. 14:6-7. According to Joachim's notion there would be a closed avant-garde society preparing Mankind for this final revolution: the early Franciscans took this as their mission (Löwith 1949: 145).

11 On the possibility of this interpretation concerning Paul's epistles see Löwith 1949: 148. 
Obviously the ideal of love has become nowadays one of the most trivialised of the Romantic concepts, but it is worth of remembering that for Schlegel it had an elaborate and highly sophisticated meaning of active joy. It offered the possibility for a new religion of the Spirit that would supersede the current institution and letter of Christianity. ${ }^{12}$

Spinoza's philosophy was a popular answer to the Enlightenment's split between knowledge and faith, reason and the emotions, the sovereign and his subjects: the path of reason and the path of religion were ultimately the same. The progression of religion presupposed a progress in the field of knowledge, the cultivation of feelings and the political emancipation of people. Both the German Romantics (the Schlegel brothers, Novalis, Schleiermacher, Tieck etc.) and the German Idealists (Fichte, Hegel and Schelling) shared this notion of the Spirit, but there were also great differences between their positions. For the German Idealists, the theology of the Spirit was something that they had learned in theological seminars. In his essay 'Glauben und Wissen' (Faith and Knowledge, 1802), Hegel claimed that the Spirit could supersede the 'divisiveness' (Entzweiung) between faith and knowledge, religion and science, haunting the Enlightenment. Hegel thought that his dialectical method could solve the problem presented by Jacobi. (HW I: 315-24.) But for the Romantics, the philosophical dialectic between the opposites of faith and knowledge was not a possible solution to this crisis of the Enlightenment. Their solution was art, Kunstreligion. Thus, the German Spinozist revival led to two major philosophical parties that should not be confused: Idealism and Romanticism. ${ }^{13}$

For Spinoza, the third kind of knowledge was an intellectual standpoint, and Hegel remained at the limits of this intellectualism. But the Romantics re-

On the notion of the Spirit in Romanticism see Pikulik 2000: 42-5.

13 Of the German Idealists, Schelling's position is the closest to Romanticism. At the end of his major work System des transzendentalen Idealismus (System of Transcendental Idealism, 180o), he claims that the highest act that perfects the philosophical system must be an artwork (Schelling 2000: 287). However, in contrast to the Romantic ideal of the fragment, Schelling claimed that a philosophical system is possible, while Schlegel claimed that a systematic presentation of complete knowledge is impossible to achieve for human beings. placed intellectual understanding by an aesthetic act. Together with Novalis, Schlegel planned to write a new bible (an absolute book) for their new aesthetic religion. Schlegel used Lessing's writings as an authority for this purpose:

Als Bibel wird das neue ewige Evangelium erscheinen, von dem Lessing geweissagt hat: aber nicht als einzelnes Buch im gewöhnlichen Sinne. . .in einem solchen ewig werdenden Buche wird das Evangelium der Menschheit und der Bildung offenbart werden. (KFSA II: 265, no. 95.)

Schlegel explicitly recognised Lessing as the prophet of the new, everlasting gospel. But in contrast to Lessing, Schlegel gave this idea a peculiarly aesthetic turn. (See Saarinen 2007: 155-63.) This is suggested in his expression of 'an eternally becoming book', which clearly refers to the most famous Athenäumfragment:

Die romantische Poesie ist eine progressive Universalpoesie. . .Die romantische Dichtart ist noch im Werden; ja das ist ihr eigentliches Wesen, daß sie ewig nur werden, nie vollendet sein kann. (KFSA II: 183, no. 116.)

The ideal of the fragment provided a definition of the new Romantic poetry as an eternally becoming poetry of the future.

The Romantics both aesthetisied and naturalised Christianity by considering Nature's poetry as a third, everlasting revelation of the Spirit. According to Schlegel:

Ich kann nicht schließen, ohne noch einmal zum Studium der Physik aufzufodern, aus deren dynamischen Paradoxien jetzt die heiligsten Offenbarungen der Natur von allen Seiten ausbrechen (KFSA II: 321-2).

The aim of this new mythology was to provide aesthetic allegories which would present in a more pedagogic and illustrative form the findings of the latest philosophy of nature, elaborated by F. W. J. Schelling and Franz Xavier von Baader:

Günstiges Zeichen, daß ein Physiker sogar der tiefsinnige Baader - aus der Mitte der Physik sich erhoben hat, die Poesie zu ahnden, die Elemente als organische Individuen $\mathrm{zu}$ 
verehren, und auf das Göttliche im Zentrum

der Materie zu deuten!' (KFSA II: 266, no. 97.)

It is worth of emphasising that the Romantic Kunstreligion was not equavalent to supernaturalism. They did not believe in a miraculous, that is to say supersensible and supernatural, revelation. Their idea really was to base the new mythology of Romantic poetry on the latest empirical findings of the natural sciences. Schlegel explicitly said that the traditional Christian revelation should be replaced by the allegories of art:

Die Philosophie lehrte uns, daß alles Göttliche sich nur andeuten, nur mit Wahrscheinlichkeit voraussetzen lasse. . .Die Offenbarung aber ist eigentlich eine für den sinnlichen Menschen zu erhabene Erkenntnis, und so tritt die Kunst sehr gut ins Mittel, um durch sinnliche Darstellung und Deutlichkeit dem Menschen die Gegenstände der Offenbarung vor Augen zu stellen. (KFSA XIII: 174.)

Lessing still presupposed quite a traditional idea of revelation. ${ }^{14}$ Exactly this kind of supernatural knowledge was impossible in Schlegel's view. According to the above quotation, the revelation is too sublime a knowledge for the human senses. Therefore it is the role of art to compensate for this defect by presenting God through allegorical means:

Die Unmöglichkeit das Höchste durch Reflexion positiv zu erreichen führt zur Allegorie d. h. zur (Mythologie und) bildenden Kunst (KFSA XIX: 25 , no. 227).

For the Romantics, the allegory of art works could provide a hint of the absolute that a philosophical system could never encapsulate (Frank 1989: 291).

The new Kunstreligion of the Spirit was not based on supernaturalism but in contrast to the results of the natural sciences. According to Friedrich Schleiermacher's definition in his Über die Religion (Speeches on Religion, 1797):

Anschauen des Universums, ich bitte befreundet Euch mit diesem Begriff, er ist der Angel

14 Lessing 1959: 2, \$1. On the other hand, the famous Ring Parable from Lessing's Nathan der Weise (Nathan the Wise, 1779) suggest that he believed in a certain relativism of divine revelation. meiner ganzen Rede, er ist die allgemeinste und höchste Formel der Religion (Schleiermacher 2004: 31).

This divine vision (Anschauung) of the universe resembles very much the Spinozian third kind of knowledge. To view the world from this vantage point means that one understands every phenomenon as the act of one God. (Schleiermacher 2004: 32.) According to a pantheistic maxim, this vision of the universe is equal to the vision of God (in both genetivus subjectivus and objectivus).

Some members of the Romantic generation performed rigorous scientific experiments themselves to give solid empirical grounds for their new religion of nature. Scientific experiments could transform into religious allegories, if they were aestheticised. As the narrator instructs us in Novalis' Die Lehrlinge zu Saïs (The Novices at Sais, 1798):

Figuren die zu jener großen Chiffernschrift zu gehören scheinen, in Krystallen, und in Steinbildungen, auf gefrierenden Wassern, im Innern und Äußern der Gebirge, de Pflanzen, der Thiere, der Menschen, in den Lichtern des Himmels, auf berührten und gestrichenen Scheiben von Pech und Glas, in den Feilspänen um den Magnet her, und sonderbaren Conjucturen des Zufalls, erblickt. In ihnen ahndet man den Schlüssel dieser Wunderschrift, die Sprachlehre derselben. .. (NW I: 201.)

Novalis himself had studied natural sciences at the university, and he was able to perform scientific experiments. Chemical, optical, magnetic and botanical experiments maintained their popularity from the Enlightenment period to that of Romanticism, but they obtained different meanings. The experiments offered a possibility for nature to 'reveal' (offenbaren) and express its secrets.

But why was this motif of allegory so important for the Romantic generation? Why is it exactly this concept that can explain the turn from the Enlightenment to Romanticism? The Romantic notion that there are mysterious allegories in nature, governed by some obscure secret society, leads us on to my second thesis. 


\section{Thesis II: Mysticism = Criticism}

Both Novalis and Schlegel introduced the motif of the secret society at the end of the 1790 os. In Novalis' Die Lehrlinge zu Saïs, the novices' mission was to unveil Isis. Isis was an ancient goddess of Egypt who represented Mother Nature. (Hadot 2006: 267.) Unveiling Isis was an allegory for 'dis-covering', that is to say, un-veiling, the secrets of nature. Schlegel seems to be familiar with the erotic nature of esoteric knowledge:

Mysterien sind weiblich; sie verhüllen sich gern, aber sie wollen doch gesehen und erraten sein (KFSA II: 269, no. 128).

Die Natur as an aesthetic, scientific and religious object was strongly feminised in German discourse. This underlay the Enlightenment's striving to control nature by dis-covering its secret laws of operation.

According to Pierre Hadot, the metaphor of unveiling nature had two basic meanings during the modern age: first, to force nature to reveal its secrets by performing scientific tests and second, to observe nature aesthetically. It had a special meaning for the generation of the Romantics: 'To unveil Isis was to realise that Nature is nothing other than Spirit, unaware of itself' (Hadot 2006: 273). This made it possible for the Romantics to bridge the lacuna created by Enlightenment science: the great gap between a dead, mechanical, determined nature and a living, organic, free Spirit (pneuma). ${ }^{15}$ Thus the aesthetic solution of early Romanticism can be considered as an attempt to provide a new answer to the central contradiction of the late German Enlightenment that had resulted in its crisis during the Pantheism Controversy.

Max Weber made the claim that art had taken the sociological function traditionally belonging to the religions of salvation. Salvation by means of art replaced the idea of salvation through God, while it was thought that art saved people from the mundane routine of the working week. (Auerochs 2006: 106-7; cf. Blumenberg 1983: 4-5.) As Bernd Auerochs has suggested, the criticism of religion practised by Aufklärer was a necessary condition for the Romantic Kunstreligion. ${ }^{16}$ This framework of explanation can clarify

15 As Karl Löwith has reminded us, Paul's pneuma in New Testament does not have this kind of modern, emancipatory meaning, but implies obedience to authority (Löwith 1949: 244).

16 Auerochs, however, objects the simplified claim that art would only have filled the vacuum of universal the role of allegory during Romanticism as well.

The allegorical explanation originates in classical antiquity. It was born in a similar context, in which there was an urge to interpret an old tradition on a totally new basis. According to Hadot:

...with the Sophists, there developed a veritable Aufklärung, or century of Enlightenment, when the existence of the gods was questioned on the grounds that it was a mere poetic fiction or social convention. Because of this, philosophers of the Platonic and Stoic traditions gradually developed a kind of doctrine of double truth. On the one hand, poetic and religious traditions were left intact. . .On the other hand, these philosophers considered that the poets of yesteryear had, in an enigmatic and hidden way, taught an entire science of nature beneath the veil of myth. . .Through skilful exegesis, called 'allegorical exegesis'..., a hidden philosophical meaning was discovered under the letter of the texts. . .the need for this method came to be felt when, as a result of the evolution of thought, traditional forms had to be reconciled with new ideas. (Hadot 2006: 41.)

Greek Sophists started to allegorise the Homeric epics, while they were alienated from Homer's aristocratic values. Similarly, Paul had to allegorise the events in the Jewish Old Testament based on his revised Christian point of view (Gadamer 1999: 93-4). In a letter to the Galatheans, Paul defines allegory as follows: 'This is being said as an allegory [ $\alpha \lambda \lambda \eta \gamma o \rho o v \mu \varepsilon v \alpha]$, for these women [Hagar and Sarah] represent two covenants' (Gal. 4:24). Christian allegory (sensus spiritualis) means a hermeneutical strategy, in which a certain location of text is read as a present sign that fulfils a previous promise made by God (Taubes 2004: 44). We can assume that the Enlightenment's criticism of religion was a similar interruption that made an allegorical relationship to religion necessary again, but for Schlegel it was aesthetic allegory that replaced the traditional Christian allegory:

Alle Schönheit ist Allegorie. Das Höchste kann man eben weil es unaussprechlich ist, nur allegorisch sagen (KFSA II, 324).

religiousness left empty when orthodox Christianity lost its legitimacy to the generation of the Romantics (Auerochs 2006: 362-3). 
Allegories are a kind of knowledge that was thought to belong only to a closed and enlightened elite. It has been a commonly held opinion that the meanings of allegories 'must not be revealed to the ignorant masses' (Hadot 2006: 55). In the eighteenth century, the idea of a secret brotherhood guarding an ancient tradition was connected with pantheism. The mysteries of nature would be revealed by shredding the veil of Isis. According to Schlegel's apocalyptic declaration in his first 'Ideen'-fragment (Ideas, 1800):

Die Foderungen und Spuren einer Moral. . . werden immer lauter und deutlicher. Sogar von Religion ist schon die Rede. Es ist Zeit den Schleier der Isis zu zerreißen, und das Geheime zu offenbaren. Wer den Anblick der Göttin nicht ertragen kann fliehe oder verderbe.

(KFSA II: 256, no. 1.)

The Freemasons especially considered themselves as the guardians of the ancient Egyptian mysteries of Isis. Lessing was one of the most famous German theorists of the Freemasons. But it is not as commonly acknowledged that Friedrich Schlegel wrote his own sequel to Lessing's Freemasonic dialogue, Ernst und Falk. Gespräche für Freimaurer (Ernst and Falk: Dialogues for Freemasons, 1778-80). (See KFSA III: 94-6.) Moreover, in Schlegel's 'Ideen' there is a suggestion for a secret association (Bund) of artists that should be organised according to the model of Freemasonry. ${ }^{17}$

Egyptomania had been in vogue during the Orientalist discourse of the Enlightenment. But Napoleon's Egyptian campaign (1798-1801) increased even further the interest in hieroglyphs and ancient Egyptian mysteries among the early German Romanticists. ${ }^{18}$ Novalis utilised this motif in Die Lehrlinge

17 'Hence the motif, which appears continually throughout the Ideas, of the necessity of constituting a secret "alliance" of artists, a League like the medieval Hansa ... or, better yet, a sort of "Masonic" Bund, wherein each member would joined to the others by an oath. . . (Lacoue-Labarthe \& Nancy 1988: 70.) See KFSA II: 259, no. 32 and 271, no. 142 ; see also von Petersdorf 1996.

18 Jan Assmann has even claimed: 'Spinozism, pantheism, and all the other religious movements of the time look to Egypt for their origins. . .The "cosmotheism" of early German Romanticism is a return of repressed paganism, the worship of the divinely animated cosmos. In a way, it is a return to ancient Egypt.'

(Assmann 1998: 142.) $z u$ Saïs: there is a brotherhood that teaches the mysteries of nature, which present in allegorical form the latest Romantic philosophy of nature. Natural phenomena seem to form a cipher code that is possible to decode if one can interpret the allegories of nature and finally lift the veil of Isis. (NW I: 199-204.)

Notwithstanding this mysticism, it is important to emphasise that the coming Age of the Spirit did not mean religious subjectivism or irrational obscurantism. To be sure, this sounds obscure and mysterious, but actually the secret societies had a certain rational function in the social situation of the Enlightenment. As Reinhart Koselleck has suggested, the age of the Enlightenment was deeply crypto-political. In the absolutism that was the political system of ancien régime there was no possibility for public political discussion. The social sphere of politics was limited to the court. Hence, the bourgeois intellectuals of the Enlightenment gathered semi-publicly in cafes or clandestinely in secret societies, as did the Freemasons. The mystic brotherhoods such as the Freemasons or Illuminates had originally had an important social function, as people of various social statuses could meet and discuss in these contexts. On the other hand, newspapers and magazines were used to create a public sphere in which old prejudices could be publicly contested, but those publications were widely controlled by censorship. Thus, the social scene of the Enlightenment was dominated by this tension between public social criticism and private political mysticism. (Koselleck 1988: passim; Karthaus 2007: 16-19.) This is the basis for my paradoxical claim that during the age of absolutism, social criticism was necessarily done privately in the forums of secret societies.

Lessing aimed to enlighten people and elevate them from the level of opinion and the fear of authority to the second kind of knowledge, and finally to the utopian Age of the Spirit. During the late German Enlightenment, the ultimate political aim of education (Bildung) was the utopian society, in which love and the Spirit would rule universally and immanently in the world. Sometimes this utopian society was thought to take the form of a new congregation: Immanuel Kant referred to this moral society conceptually as the invisible church (die unsichtbare Kirche; Kant 1966: A 134). In the end, all authoritarian divisions between people would be superseded during the education of mankind. ${ }^{19}$ This idea had a critical

19 The political idea of Third Age penetrates the Occidental utopian imagination from the Hegelian 
potential that could be turned against the Lutheran Obrigkeitslehre. Literary censorship was one among a number of reasons for allegorising teachings during the late eighteenth century. (Nivala 2011b: 97-102.)

There were subtle political ideas that were thought to be impossible to communicate publicly in such closed societies as the late eighteenth century German states were. According to Koselleck:

Freemasonry constitutes a focused, powerful counter-movement against that inescapable evil', the matrix and subject of State policy. . . The initiated Mason recognises the inevitability of States and social differences, and hence also of politics, but his ultimate goal is to prevent the evils brought on by politics 'from making greater inroads than necessity dictates. To render their effects as harmless as possible.' This inevitably brought the Masons into the sphere of national politics, even if theirs was a moral purpose. . .The ultimate goal of the Masonsand one Lessing only hints at - was as far as possible to make the state superfluous. (Koselleck 1988: 88.)

The secret societies aimed to exert a private moral influence on the nobility who carried on the politics at court. The state politics of absolutism as such were seen as an evil sphere of domination, and the utopia of the Masons was ultimately to supersede the state. Schiller's cosmopolitan verse Alle Menschen werden Brüder! from Ode an die Freude (1785) was written on the plate of Johannisloge in Dresden. Schiller wrote it for Christian Körner, who was a Freemason, and its intention was obviously Spinozian: to celebrate the brotherhood and unity of all mankind. Hence, there was an essential connection between the mysticism of secret societies and the most radical political criticism of their time.

Lessing's Age of the Spirit aimed at this kind of utopian unification in the name of universal love between people. But according to Koselleck, Lessing was farsighted enough to understand that the real necessities of politics, that is to say, the social differences between people, could not be superseded in

absolute spirit to Auguste Comte's positivism, Karl Marx's notion of future communist society and even National Socialism's idea of Third Reich (Löwith 1949: 208-13). In other words, the idea of a utopian Third Age was not mere eccentricity of the Romantics, but a quite common utopian trend in nineteenth century intellectual history. reality (Koselleck 1988: 89). There is an anti-utopian thread in Lessing's thought that also influenced Schlegel's political theory at the beginning of nineteenth century. Hence, the mystical level in Schlegel's thought had a certain elitist implication. Only the elected ones knew how to decipher his political allegories correctly. (Nivala 2011b: 98.) His league of artists would be an exclusive association, while, having witnessed the political terror during French Revolution, Schlegel became more and more convinced that revolutionary ideas should be limited only to a small, progressive vanguard. He wrote:

Jetzt da alle äußern Verhältnisse zerstört und aufgelöst sind in eine chaotische Masse tyrannisch revolutionär Gleichheit, scheint dieser Geist und diese Kraft beinah verschwunden. . . (KFSA III: 102).

The utopian spirit of morality, the ideal of democratic equality, had led to situation in which the presupposition of politics, the existence of social differences, was questioned.

The politics of Schlegel's late Romanticism often seem reactionary and conservative, but his point was to protect the essence of politics: social differences. If all the divisions between people could be superseded (thus inaugurating the utopian Age of the Spirit), it would mean a transition to a stateless, non-political community. Absolute democracy would necessarily mean the dilution of politics, while the negotiations between different social classes is the essence of politics. Schlegel rigorously avoids the reduction of the sphere of politics to morality:

Wo Politik ist oder Ökonomie, da ist keine Moral (KFSA II: 266 , no. 101). ${ }^{20}$

20 Klaus Peter has claimed the opposite: 'Die konkrete Politik der französischen Revolutionäre blieb Friedrich Schlegel ebenso fremd wie später die Metternichs. Der Schleier der Moral, den die Aufklärung nach Koselleck "ständig webend vor sich hertrug und den zu zerreißen sie niemals imstande war" verdeckte noch in der Romantik den Blick auf die Politik. . ' (Peter 1980: 10.) According to his claim, both Aufklärer and the Romantics operated behind 'the veil of morality', and could never understand the real necessities of politics. The problem of Peter's reading is that he does not take into account sufficiently Schlegel's actual writings concerning politics. The early (radical) Schlegel, for instance, defended democracy and the right of rebellion, and he objected to 
I would suggest that regardless of Schlegel's pantheism and mysticism, he is not as utopian a thinker as it at first appears. It is exactly the function of mystic association to cover a place and possibility for politics in the original sense. Although Schlegel and other Romantics occasionally seemed to object to open and public discussion, they had socio-historically understandable reasons for that. Furthermore, this elitist notion of Romanticism is not opposed to the Enlightenment, but continues Lessing's thoughts concerning the necessary function of secret societies during the political system of absolutism.

Paradoxically, it is precisely Schlegel's elitism, his ethos of distancing oneself from the mob (Pöbel) that is the condition of possibility for politics. This makes Schlegel emphasise the political function of secret societies and the limits of contemporary publicity:

Ferne sei es von uns, auch nur die Zwecke der wahren Philosophie, geschweige denn ihren ganzen Inhalt in öffentlichen Reden und Schriften dem Pöbel preisgeben zu wollen! Nur allzu deutlich hat uns erst die Reformation und mehr noch Revolution gelehrt, was es auf sich habe mit der unbedingten Öffentlichkeit. . .Nicht in den Schriften also und Buchstaben und Systemen ist die Philosophie beschlossen; so eng läßt sich der unendliche Geist nicht fesseln und binden. (KFSA III: 101.)

In Luther's translation of the Bible, the opposition between the spirit and the letter of the written law was translated as Geist and Buchstaben. ${ }^{21}$ This is an

the exclusion of people from government on grounds of gender or property. I cannot understand why those arguments would be moralistic rather than political ones. See KFSA VII: 11-25; Beiser 1992: 250-2. Later on, Schlegel's politics took a conservative turn, but they still remained political opinions.

21 Schlegel's distinction between the material, superficial letter and the inner spirit can be understood as a German reaction to the trauma of the late modernisation process. 'Conflict between Old and New Testament gods, between the God of the Word and the God of the Deed, played an important symbolic role in all nineteenth century German culture. This conflict, which is articulated in German writers and thinkers from Goethe and Schiller to Rilke and Brecht, was in fact a veiled debate about the modernisation of Germany: should German society throw itself into "Jewish" material and practical activity, that is, into economic development and construction, along with liberal political reform, in the manner of England, application of Paul's famous claim that 'the letter kills, but the Spirit gives life' (2. Cor. 3:6). Schlegel referred constantly to those Pauline concepts which allegorise inner spirituality as external events. The opposition of Geist/Buchstabe was absolutely essential for Schlegel's thought at all levels: the letter is something external, dead and mechanical, while the Spirit is internal, living and organic (Pikulik 2000: 42-5). ${ }^{22}$ According to Paul: 'a person is not a Jew because of his appearance, nor is circumcision something external and physical. No, a person is a Jew inwardly, and circumcision is a matter of the heart, by the Spirit, not by a written law.' (Rom. 2:28-9.)

This politico-theological motif manifests interestingly in the contemporary context. There was a relatively recent debate between Alain Badiou and Giorgio Agamben concerning the political essence of Pauline Messianism. According to Badiou (2003: 109), it supersedes all differences of identity (social class, gender, ethnic origin, nationality etc.). In contrast to this, Agamben (2005: 51-2) claims that Paul's Messianism preserves the differences between various identities. Obviously this debate concerns one of the most difficult questions of our age: should politics be based on universalism or take into account local peculiarities? Agamben makes an interesting distinction between eschatology and Messianism: the former involves a belief in the ultimate disappearance of all social divisions, but the latter amounts to a strategy of subsisting with social divisions until the Messiah arrives. Utopian eschatology tries to abolish differences-Messianism strives to comprehend the differences as differences. ${ }^{23}$ In other words, eschatology aims at a utopian Age of the Spirit that would replace the level of politics with a utopian idea of equality, while political Messianism tries to maintain the differences of identity in order to preserve the condition of the possibility of authentic politics.

France and America? Or, alternatively, should it hold aloof from such "worldly" concerns and cultivate an inward-looking “German-Christian” way of life?' (Berman 1988: 47.)

22 On the opposition of mechanical and organic in Romanticism see Nivala $2011 \mathrm{~b}$.

23 According to Agamben (2005: 53-8), Paul had a highly elaborated conceptual network: there is 1) the whole, 2) a part and 3) a remnant. In other words, epistemological and political questions cannot be dealt with in terms of the traditional idea of an organic whole structured teleologically in parts without taking into account a remnant that cannot be reduced either to the whole or to the parts of the whole. 


\section{To conclude: the Romantics and authority}

In this paper, I have discussed Romanticism in relation to two presuppositions of the Enlightenment. It is already important to recognise that the Enlightenment actually had some presuppositions (Voraussetzungen). Hans-Georg Gadamer has criticised the Enlightenment by arguing that dogmatism and believing in authority are actually necessary conditions for scientific practice. This is because the idea that one could leave behind all one's prejudices is unfortunately impossible. The Enlightenment's fantasy of a prejudice-free discussion would actually imply that it would be possible to leave behind the current historical situation.

Furthermore, Gadamer (1990: 281-5) claims that the Romantics understood the necessity of tradition and a certain belief in authority. It is possible to find such kinds of arguments in Schlegel's writings. For example, he wrote in his essay about Lessing:

Aufklärung, oder Vertilgung aller Vorurteile, wäre an sich ein schönes Unternehmen. Man nehme nur alle die Hemmungen weg und die unechten Zusätze, und es wird das hohe Licht der Vernunft sich schon von selbst offenbaren, ohne alles äußere Zutun. . .Wie mancher, der sich viel damit weiß, daß er die Vorurteile des Christen abgelegt, oder vielmehr samt allem Guten, vomit sie verwebt waren, zugleich abgeworfen hat, ist noch bis sein tieftes Wesen ganz umwunden von den Vorurteilen seiner Nation, seines Standes, des bürgerlichen Lebens, seines Kreises, überhaupt der gebildeten Gesellschaft; des Zeitalters endlich, dessen herrschender Charakter Eitelkeit und Dünkel und die damit notwendig verbundene Unkenntnis seiner selbst ist. (KFSA III: 9.)

Schlegel and other inaugurators of Romantic hermeneutics all agreed that the criticique of prejudices cannot mean that one can jump straight to a prejudice-free state of discussion. This kind of ahistorical objective is not possible for human beings. This is the great difference between the Enlightenment and Romanticism.

But this does not mean that the early Romantic revival of religion was the equivalent of regressing back to earlier forms of superstition. According to Schlegel, the most essential ideals of Lessing's criticism were 'Prüfung, freimütige und sorgfältige Prüfung der Meinungen andrer, Widerlegung manches gemeingeltenden Vorurteils' (KFSA III: 52). On another occasion he condensed his ideal of criticism thus: 'Auch ist kritisch wohl etwas, was man nie genug sein kann' (KFSA II: 213, no. 281). Gadamer's claim that the Romantics believed in the authority of tradition is problematic. I would suggest that especially the early Romantics rather shared the social rebelliousness of the Enlightenment. It would demand a certain amount of interpretative violence, if one would like to claim that Lord Byron supported the authority of tradition, for instance. It seems that Gadamer himself tries to argue for his own conservative position with the aid of the Romantics.

Asko Nivala, MA, is a doctoral student in cultural history at the University of Turku. He received his MA degree in 2007. His research focuses on German early Romanticism and especially on Friedrich Schlegel, who was one of the most famous members of the Romantic movement in Jena in the 1790s. In his study, Nivala disentangles the cultural implications

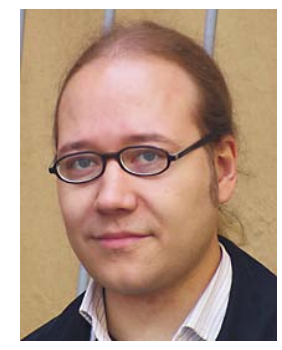
which underlie the early Romantic philosophy of history. One of his essential research methods is the metaphorological analysis of philosophical concepts. His PhD research is funded by the Finnish Cultural Foundation. His other research interests include the philosophy of history, the German Enlightenment and the recent discussion on political theology. Besides his academic work, Nivala is also an internationally acknowledged performance artist as a member of Finnish performance group MRCVE. E-mail: asko.nivala(at)utu.fi

\section{Bibliography}

Agamben, Giorgio 2005. The Time That Remains: a Commentary on the Letter to the Romans. (Il tempo che resta. Un commento alla Lettera ai Romani, 200o.) Transl. Patricia Dailey. Stanford: Stanford University Press.

Assmann, Jan 1998. Moses the Egyptian: the Memory of Egypt in Western Monotheism. Cambridge: Harvard University Press.

Auerochs, Bernd 2006. Die Entstehung der Kunstreligion. Göttingen: Vandenhoeck \& Ruprecht.

Badiou, Alain 2003. Saint Paul: the Foundation of Universalism (Saint Paul. La fondation de l'universalisme, 1997). Trans. Ray Brassier. Stanford: Stanford University Press.

Berman, Marshall 1988. All That is Solid Melts into Air: the Experience of Modernity. New York: Penguin Books.

Beiser, Frederick C. 1987. The Fate of Reason. German Philosophy from Kant to Fichte. Cambridge: Cambridge University Press.

-1992. Enlightenment, Revolution, and Romanticism: the Genesis of Modern German Political Thought 1790-1800. Cambridge: Harvard University Press. 
-2000. 'The Enlightenment and Idealism.' In: Karl Ameriks (ed.), The Cambridge Companion to German Idealism. 18-36. Cambridge: Cambridge University Press.

-2006. The Romantic Imperative: the Concept of Early German Romanticism. Cambridge \& London: Harvard University Press.

Blumenberg, Hans 1983. The Legitimacy of the Modern Age. (Die Legitimität der Neuzeit, 1966.) Trans. Robert M. Wallace. Cambridge: MIT Press.

Deleuze, Gilles 1992. Expressionism in Philosophy: Spinoza. (L'idéa d'expression dans la philosophie de Spinoza, 1968.) Trans. Martin Joughin. New York: Zone Books.

Frank, Manfred 1989. Einführung in die frühromantische Ästhetik. Vorlesungen. Frankfurt a. M.: Suhrkamp.

Gadamer, Hans-Georg 1990. Wahrheit und Methode. Grundzuüge einer philosophischen Hermeneutik. Tübingen: Mohr. (First published in 1960.)

-1999. 'Klassische und philosophiche Hermeneutik.' In: Hans-Georg Gadamer, Gesammelte Werke 2. Hermeneutik II. Tübingen: Mohr. (First published in 1968.)

Hadot, Pierre 2006. The Veil of Isis: an Essay on the History of the Idea of Nature. (Le Voile d'Isis: Essai sur l'histoire de l'idée de Nature, 2004.) Trans. Michael Chase. Cambridge: Harvard University Press.

Henrich, Dieter 2008. Between Kant and Hege:. Lectures on German Idealism. Cambridge: Harvard University Press.

HW = Hegel, Georg Wilhelm Friedrich 1999. Hauptwerke in sechs Bände. Hamburg: Meiner.

Jacobi, Friedrich Heinrich 200o. Über die Lehre des Spinoza in Briefen an den Herrn Moses Mendelssohn. Hamburg: Meiner. (First published in 1785.)

Kant, Immanuel 1966. 'Die Religion innerhalb der Grenzen der bloßen Vernunft.' In: Wilhelm Weischedel (ed.), Schriften zur Ethik und Religionsphilosophie. Darmstadt: Wissenschaftliches Buchgesellschaft. (First published in 1793.)

-2004. Kritik der reinen Vernunft. Frankfurt a. M.: Suhrkamp. (First published in 1781/7.)

Karthaus, Ulrich 2007. Sturm und Drang. Epoche - Werke - Wirkung. München: Beck.

KFSA = Schlegel, Friedrich 1958-. Kritische FriedrichSchlegel-Ausgabe I-XXXV. Ed. Ernst Behler et al. Paderborn, München, Wien \& Zürich: Schöningh.

Kondylis, Panajotis 2002. Die Aufklärung im Rahmen des neuzeitlichen Rationalismus. Hamburg: Meiner. (First published in 1981.)

Koselleck, Reinhart 1988. Critique and Crisis: Enlightenment and the Pathogenesis of Modern Society. (Kritik und Krise. Eine Studie zur Pathogenese der bürgerliche Welt, 1959.) Cambridge: The MIT Press.

Krauss, Werner 1980. 'Französische Aufklärung und deutsche Romantik.' In: Klaus Peter (ed.), Romantikforschung seit 1945. 168-79. Königstein: Anton Hain. (First published in 1962.)

Lacoue-Labarthe, Philippe \& Jean-Luc Nancy 1988. The Literary Absolute: the Theory of Literature in German Romanticism. (L'Absolu littéraire. Théorie de la lit- térature du romantisme allemand, 1978.) Trans. Philip Barnard \& Cheryl Lester. Albany: State University of New York Press.

Lessing, Gotthold Ephraim 1959. 'Die Erziehung des Menschengeschlechts.' In: Kurt Rossmann (ed.), Deutsche Geschichtsphilosophie von Lessing bis Jaspers. 1-29. Birsfelden-Basel: Schibli-Doppler.

Löwith, Karl 1949. Meaning in History: the Theological Implications of the Philosophy of History. Chicago: University of Chicago Press.

Nivala, Asko 2011a. 'Friedrich Schlegel and the Principles of the Enlightenment.' In: Minna Ahokas, Timo Kaitaro \& Charlotta Wolff (eds), The Enlightenment: Critique, Myth and Utopia. 201-19. Frankfurt a. M.: Peter Lang.

-2011b. 'Chemical Age: Presenting History with Metaphors.' In: Bruce Johnson \& Harri Kiiskinen (eds), They Do Things Differently There: Essays on Cultural History. 81-108. Turku: k\&h.

NW = Novalis 1999. Werke, Tagebücher und Briefe Friedrich von Hardenbergs I-III. Ed. Hans-Joachim Mähl \& Richard Samuel. Darmstadt: Wissenschaftliche Buchgesellschaft.

Peter, Klaus 1980. Stadien der Aufklärung. Moral und Politik bei Lessing, Novalis und Friedrich Schlegel. Wiesbaden: Akademische Verlagsgesellschaft Athenaion.

Petersdorf, Dirk von 1996. Mysterienrede. Zum Selbstverständnis romantischer Intellektueller. Tübingen: Max Niemeyer.

Pikulik, Lothar 200o. Frühromantik. Epoche - Werke Wirkung. München: Beck.

Saarinen, Veli-Matti 2007. The Daybreak and Nightfall of Literature: Friedrich Schlegel's Idea of Romantic Literature between Productive Fantasy and Reflection. Frankfurt a. M.: Peter Lang.

Schanze, Helmut 1966. Romantik und Aufklärung. Untersuchungen zu Friedrich Schlegel und Novalis. Nürnberg: Hans Carl.

Schelling, Friedrich Wilhelm Joseph 2000. System des transzendentalen Idealismus. Hamburg: Meiner. (First published in 180o.)

Schleiermacher, Friedrich 2004. Über die Religion: Reden an die Gebildeten unter ihren Verächtern. Hamburg: Meiner. (First published in 1797.)

Spinoza, Baruch de 1986. Spinoza's Ethics and On the Correction of the Understanding. Trans. Andrew Boyle. London: Dent.

Stockinger, Ludwig 2003. 'Die Auseinandersetzung der Romantiker mit der Aufklärung.' In: Helmut Schanze (ed.), Romantik-Handbuch. 79-106. Stuttgart: Kröner.

Taubes, Jacob 2004. The Political Theology of Paul. (Die Politische Theologie des Paulus, 1993.) Trans. Dana Hollander. Stanford: Stanford University Press.

Timm, Hermann 1974. Gott und die Freiheit. Studien zur Religionsphilosophie der Goethezeit. Frankfurt a. M.: Vittorio Klostermann.

Wiese, Benno von 1927. Friedrich Schlegel. Ein Beitrag zur Geschichte der romantischen Konversionen. Berlin: Julius Springer. 